American J. of Engineering and Applied Sciences 4 (2): 187-200, 2011

ISSN 1941-7020

(C) 2011 Science Publications

\title{
Termite Damage to Buildings: Nature of Attacks and Preventive Construction Methods
}

\author{
Abdel Ghaly and Skai Edwards \\ Department of Process Engineering and Applied Sciences, \\ Dalhousie University, Halifax, Nova Scotia, Canada
}

\begin{abstract}
Problem statement: Termites are an essential member of the soil ecosystem and are found throughout the world. In their natural environment, they improve soil $\mathrm{pH}$, organic carbon content, water content and porosity by cycling dead organics. However, they can negatively impact human welfare by causing damage to unprotected timber structures, underground cables, earthen dams, irrigation ditches and farming equipment. Globally, the annual economic cost of termite damage and termite prevention is estimated in the billions. However, in underdeveloped countries data on damage is unavailable and it is difficult to estimate the cost of repair as funds are also not available. This study aimed at addressing termite damage in Zambia as a model underdeveloped country by: (a) identifying the injurious species of termites found in the country, (b) reviewing the factors affecting the natural durability of wood, (c) determining the nature of termite damage to timber, (d) determining the most common faulty construction practices which lead to termite entry and infestation in buildings, (e) reviewing chemical and biological techniques for prevention of damage to wood and (f) developing construction methods that will prevent termite entry to buildings. Approach: Several houses in selected villages, towns and cities in different locations in Zambia were chosen for study (ten houses in each location). The injurious species of termites and the natural durability of construction wood were assessed. The damage to timber was evaluated and the faulty construction practices that allowed termite entry to buildings were identified. Results: The interior of each house and the surrounding area were examined for the presence of termites and termite related damage. Termites were found to gain entry to buildings by a number of paths. These included creating bore holes through walls, crawling through cracks in the foundation and climbing through the roof. Conclusions: To prevent termite entry into buildings multiple approaches must be used. Before construction begins all nests and palatable wood must be cleared from the site. Once clearing is completed and before construction begins, wood should be selected based on its natural repellency. If no naturally repellent timber is available wood should be impregnated with a chemical preservative. A chemical barrier must be created by treating all exposed wood in the structure with termiticides and all wood should be placed above a concrete footing. Once materials have been selected additional constructional preventative measures consisting of internal preventive measures within the plinth and external preventive measure in the form of concrete grooves and interlocking apron floors around the periphery building should be put in place. Educational and promotional activities will further lead to prevention of termite attack to buildings.
\end{abstract}

Key words: Building techniques, termite damage, construction methods, termite control, chemical treatment, natural durability, termite attacks, Persistent Organic Pollutants (POPs), soil ecosystem, cycling dead organics

\section{INTRODUCTION}

Termites are an essential member of the soil ecosystem and are found throughout the world. Their presence is particularly noticeable in tropical and subtropical regions where they represent a significant portion $(10 \%)$ of the animal biomass (Donovan et al.,
2007). When the estimate is refined to include only soil insect biomass this value rises to $95 \%$ (Donovan et al., 2007). The natural activities of termites help to improve soil $\mathrm{pH}$, organic carbon content, water content and porosity (Black and Ozwakol, 1997; Donovan et al., 2001; Dawes, 2010). By improving and adjusting these soil parameters termites assist in creating conditions

Corresponding Author: Abdel Ghaly, Professor, Department of Process Engineering and Applied Sciences, Dalhousie University, Halifax, Nova Scotia, Canada Tel: (902) 494-6014 
conducive to primary production. However, when introduced to urban areas this same act of cycling dead organics can have negative economic impacts; devaluing property, damaging crops and necessitating household repairs. Once entering a structure, termites damage unprotected cellulosic materials such as timber, underground cables, earthen dams, irrigation ditches and farming equipment (Watson and Perry., 1981; Salman et al., 1982; DeGroot, 1983; Wood, 1991; and Tsunoda, 2005). For homeowners this is a serious problem as a termite colony can structurally compromise a building`s integrity resulting in permanent damage and loss of value. The annual economic cost of termite damage and termite prevention, worldwide is estimated in the billions (Ahmed and French, 2005).

In Australia and China, termite infestations are widespread. It is estimated that $20 \%$ of Australian homes and up to $90 \%$ of Chinese homes south of the Yangtze River are affected by termite damage GEI, 2005 (MRP, 2010). Their economic security plans have enabled these countries to catalog, prevent and combat the termite damage done to their buildings and crops. However, in underdeveloped countries, especially in Africa, the funds for maintenance and damage prevention are not as readily available. A summary of data for some affected countries is presented in Table 1. The economic losses associated with termite damage for Malaysia, India, Australia, China, Japan and The United States are 10, 35, 100, 375, 800 and 1,000 million US dollars, respectively. A possible explanation for the unusually high cost of Japanese termite damage is that a large number of Japanese homes $(50 \%)$ are constructed of wood (Tsunoda, 2005).

Termite damage to buildings in tropical countries is a serious concern. This is in part due to the diversity of termites in these areas. Africa alone has 660 distinct termite species (Uys, 2002). An estimate of the annual losses caused by termite attacks in this region is currently unavailable due to the difficulty in collecting such information from individual householders. However, there has been an increased appreciation of the importance of termite damage to buildings due to the rising costs of repairs and maintenance. Due to poor building techniques, many houses are attacked by termites within a few years of construction. This necessitates a chemical treatment that may rapidly deteriorate under the tropical conditions of high humidity (Cassens et al., 1995). This costly treatment is added to the price of replacing damaged furniture and household effects.

The threat of damage to buildings and the high cost of repairs create a need for constant vigilance on the part of home owners (Wood, 1991). Builders must be aware of and look to eliminate the economic losses associated with termite activity.
Table 1: Annual economic losses associated with termite activity

\begin{tabular}{llll}
\hline & $\begin{array}{l}\text { Number of } \\
\text { Termite } \\
\text { Country }\end{array}$ & $\begin{array}{l}\text { Costs associated } \\
\text { with termite activity } \\
\text { (US \$ } 10^{6} / \text { year) }\end{array}$ & Reference \\
\hline Malaysia & NA & $8-10$ & Verma et al. $(2009)$ \\
India & NA & 35.12 & Verma et al. $(2009)$ \\
Australia & NA & 100 & Scholz et al. $(2010)$ \\
China & 482 & $300-375$ & GEI (2005) \\
Japan & 21 & 800 & Verma et al. $(2009)$ \\
USA & 50 & 1,000 & Resh and Carde $(2009)$ \\
\hline NA.
\end{tabular}

Chemical treatments, while effective in treating initial attacks, do not provide a complete answer as untreated cellulosic materials in buildings may still be attacked and the treatment will deteriorate over time (Ahmed and French, 2005; Lewis, 2008; Verma et al., 2009). An immediate need is a code of practice for prevention of termite attack by construction methods.

The main objectives of this study were to: (a) identify the injurious species of termites found in Zambia, (b) review the factors affecting the natural durability of wood, (c) determine the nature of termite damage to timber, (d) determine the most common faulty construction practices which lead to termite entry and infestation in buildings, (e) review chemical and biological techniques used for prevention of termite damage to wood and (f) develop construction methods that will prevent termite entry to buildings.

\section{MATERIALS AND METHODS}

Project site: Zambia is a landlocked country in South Central Africa Fig. 1. It shares borders with The Democratic Republic of Congo to the north, Tanzania to the northeast, Malawi to the east, Mozambique to the southeast, Zimbabwe to the south, Botswana and Namibia to the southwest and Angola to the west. The country sits on a high plateau between 8 and 18 degrees latitude south and between 22 and 36 degrees longitude east. The country has a surface area of 752,620 square kilometers with three distinct topographies: mountain ranges, high plateaus and low valleys. The landscape is mainly savannah. However, the country has grasslands and wooded areas of several species. Several flood areas exist in the swampy flat plains of Kafue, Bangweulu and Lukanga. There are wide seasonal variations in temperature and rain with three distinct seasons: (a) a cool and dry season from May to August when the temperature varies from $10-25^{\circ} \mathrm{C}$, (b) a hot and dry season from September to November when the temperature varies from $25-35^{\circ} \mathrm{C}$ and (c) a warm and wet season from December to April when the temperature varies from $15-30^{\circ} \mathrm{C}$. Generally, September is the hottest month and the main rainy season starts in mid-November. Once the rains begin heavy tropical storms typically last into April. This results in an average annual precipitation of $125 \mathrm{~cm}$ in the North and $78 \mathrm{~cm}$ in the South. 


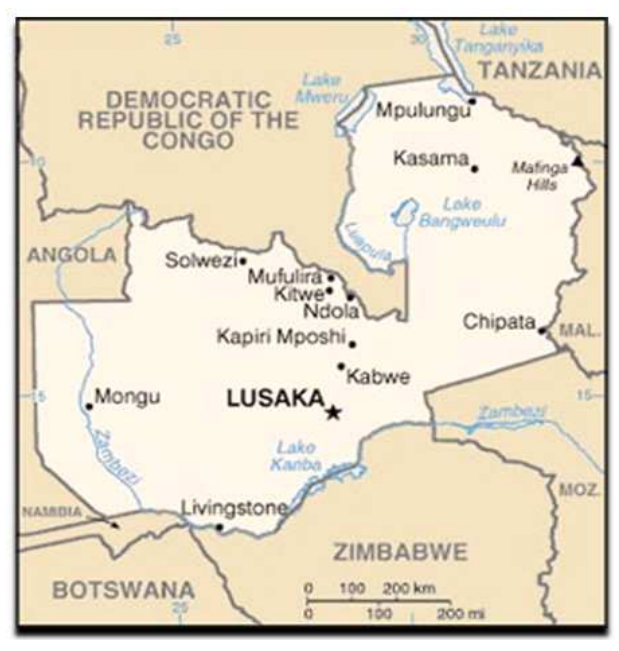

Fig. 1: Map of Zambia USDOS, 2010

Procedure: A survey was first conducted to determine the injurious species of termites in Zambia and the natural durability of wood used in construction. Information was gathered from government reports, published materials and interviews with farmers, house occupants, government officials and researchers.

Several houses in selected villages, towns and cities in 8 locations (Lusaka, Kabwe, Ndola, Solwezi, Chipata, Kasama, Mongu and Livingstone) were then chosen for the field study on termite damage to buildings. Ten houses were selected in each locality and a total of 80 houses were inspected. The damage to timber was evaluated and the faulty construction practices that allowed termite entry to buildings were identified. The interior of each house and the surrounding area were examined for the presence of termites and the damage they caused. Where possible, termites were collected and preserved in $70 \%$ alcohol for later identification. During the study, termite foraging tubes were discovered on exterior walls but no termites were found in the tubes. It appeared that they were live tubes because when removed, occupants reported that new tubes would appear the following day. Live workers and soldiers were found in wood samples found on the grounds surrounding these houses.

In order to confirm these empirical observations a complete review of literature on the nature of termite damage to timber was made. This review was extended to include the chemical and biological techniques used for preventing damage to wood. Finally, a suggested design was proposed to prevent termite entry to buildings and recommendations were made for the implementation of the proposed construction method.

\section{RESULTS}

Termite entry to buildings: Several houses in select villages, towns and cities in Zambia were investigated and a number of faulty practices leading to termite entry into buildings were observed. These faulty practices include poor workmanship relating to timber selection and placement, foundation work, interior and exterior wall work and roof sealing as shown in Table 2. The termite entry pathways are illustrated in Fig. 2.

Termites were observed to gain access to structures by a number of paths. They bored holes through untreated or aged timber or soft mortar and travelled up through the walls of the building. Alternatively, where foundations were improperly installed, termites gained access through the clay floor. In structures where both the walls and foundation were inedible, the termites could enter through cracks between the two materials. Aging concrete floors were seen to crack which allowed an additionally pathway for termite entry. In structures with gaps between internal and external joints, termites were seen to enter through these gaps.

Preventative construction designs: By providing internal and external barriers to termite entry structures can be protected from damage. Internal preventative measures within the plinth consist of well-rammed clean earth filling, staggered sand layers and a continuous concrete slab expanding over the entire plinth area as shown in Fig. 3. External preventative measures, designed in the form of concrete grooves and interlocking apron floors around the periphery, are shown in Fig. 4. In addition to these methods an antitermite metal cap is recommended to prevent termite scaling service pipes as shown in Fig. 5.

\begin{tabular}{|c|c|}
\hline Item & Faulty practices \\
\hline \multirow[t]{5}{*}{ Timber work } & Use of termite infested wood \\
\hline & Use of unseasoned or low durability untreated wood \\
\hline & Use of timber components in badly ventilated dark places \\
\hline & Structural timber in contact with the ground \\
\hline & Cellulosic materials buried under the ground near building \\
\hline \multirow[t]{6}{*}{ Foundation } & $\begin{array}{l}\text { Use of brick walls with mud mortar in foundations with non- } \\
\text { continuous clay floor over earth filling }\end{array}$ \\
\hline & Use of brick walls with lime mortar in foundations \\
\hline & $\begin{array}{l}\text { Use of brick walls with cement mortar in foundation with } \\
\text { non-concrete slab over earth filling }\end{array}$ \\
\hline & Use of hollow block walls with lime mortar in foundations \\
\hline & With non-continuous concrete slab over earth filling \\
\hline & $\begin{array}{l}\text { Use of hollow block walls with cement mortar in foundations } \\
\text { with non-continuous concrete slab over earth filling }\end{array}$ \\
\hline \multirow[t]{3}{*}{ Walls } & $\begin{array}{l}\text { Building exterior walls with cement mortar directly over } \\
\text { foundation with detached concrete floor }\end{array}$ \\
\hline & $\begin{array}{l}\text { Building intermediate walls over non-continuous concrete } s \\
\text { lab and detached apron floor }\end{array}$ \\
\hline & $\begin{array}{l}\text { Building intermediate walls over continuous concrete slab } \\
\text { but detached apron }\end{array}$ \\
\hline Roof & Leakage in roof \\
\hline
\end{tabular}


Am. J. Engg. \& Applied Sci., 4 (2): 187-200, 2011

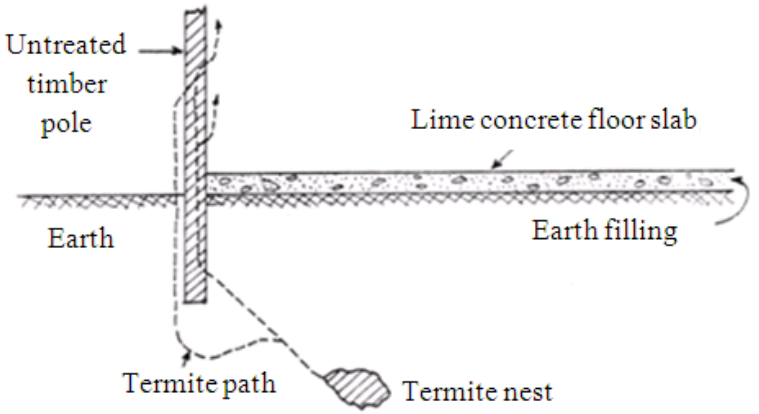

(a)

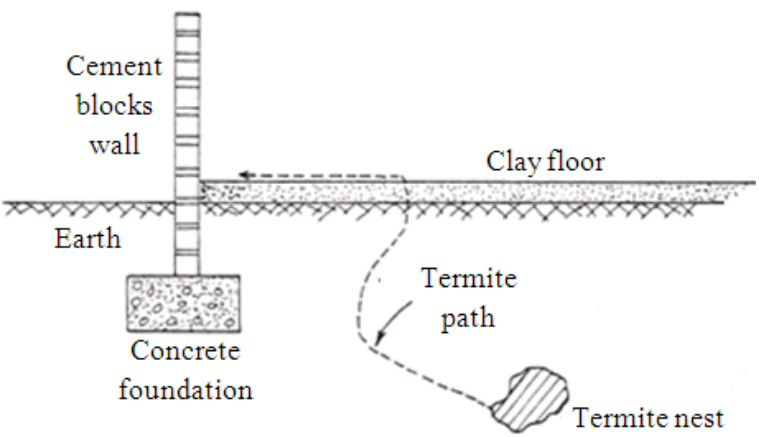

(c)

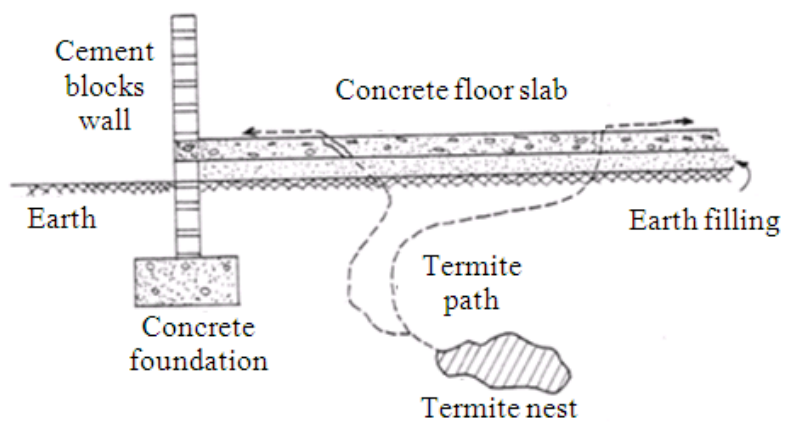

(e)

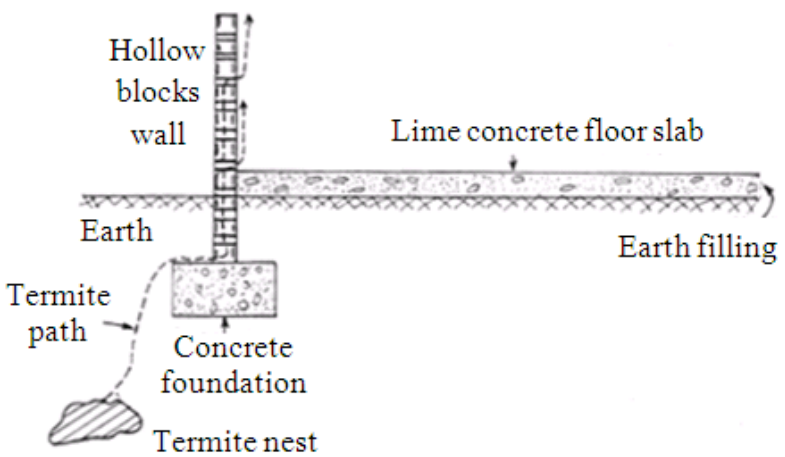

(b)

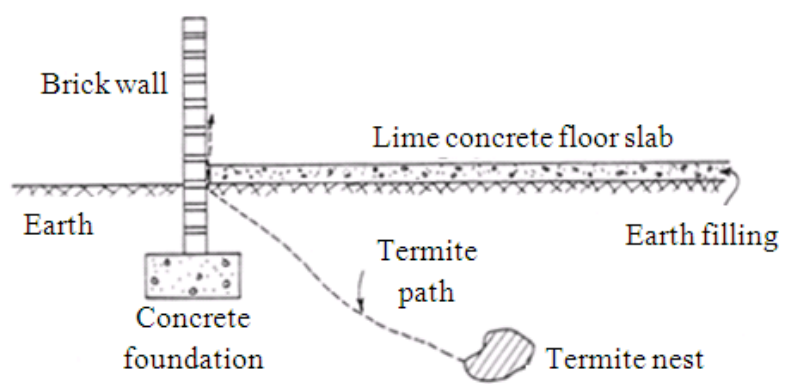

(d)

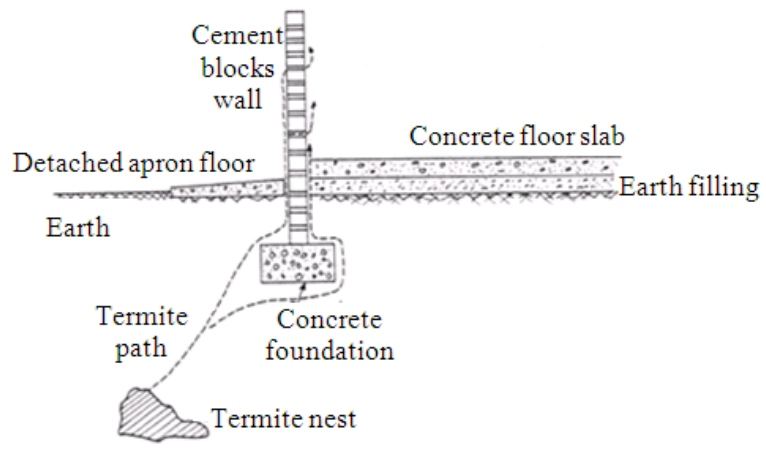

(f)

Fig. 2: Termite entry pathways (a) Through untreated timber poles; (b) Through hollow blocks; (c) Through clay floor slab; (d) Between slab and wall joints; (e) Through cracks in concrete floor; (f) Between internal and external joints

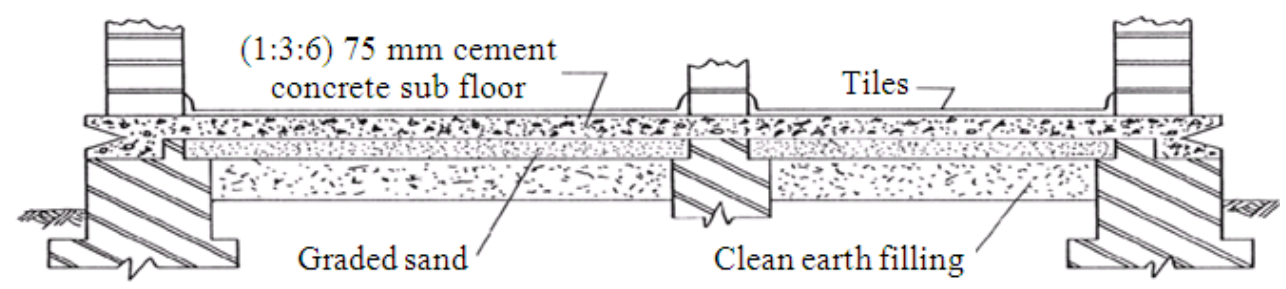

Fig. 3: Internal preventative measures 
Am. J. Engg. \& Applied Sci., 4 (2): 187-200, 2011

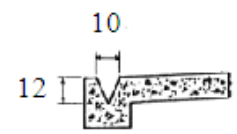

(A) Detail of horizontal Anti-termite groove

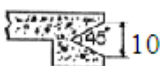

(B) Detail of vertical anti-termite groove

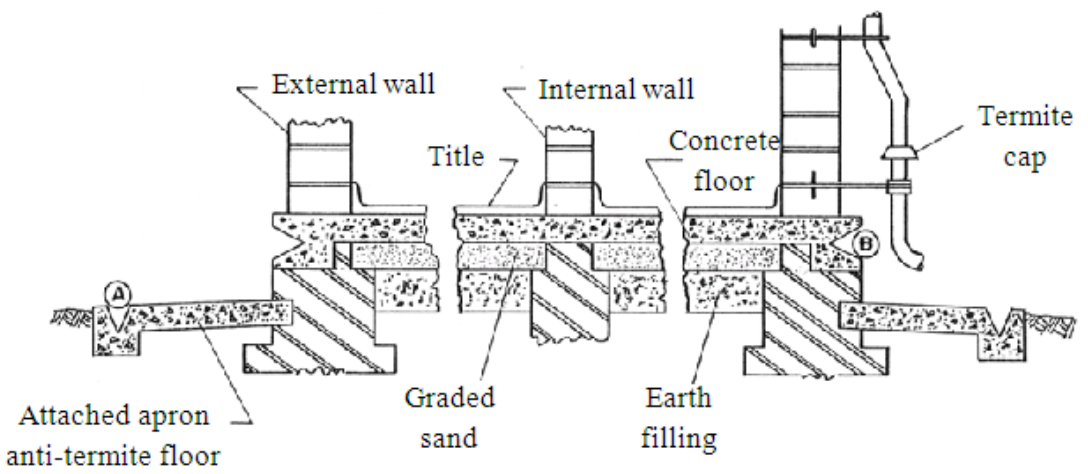

Fig. 4: External preventative measures (Dimensions in $\mathrm{cm}$ )

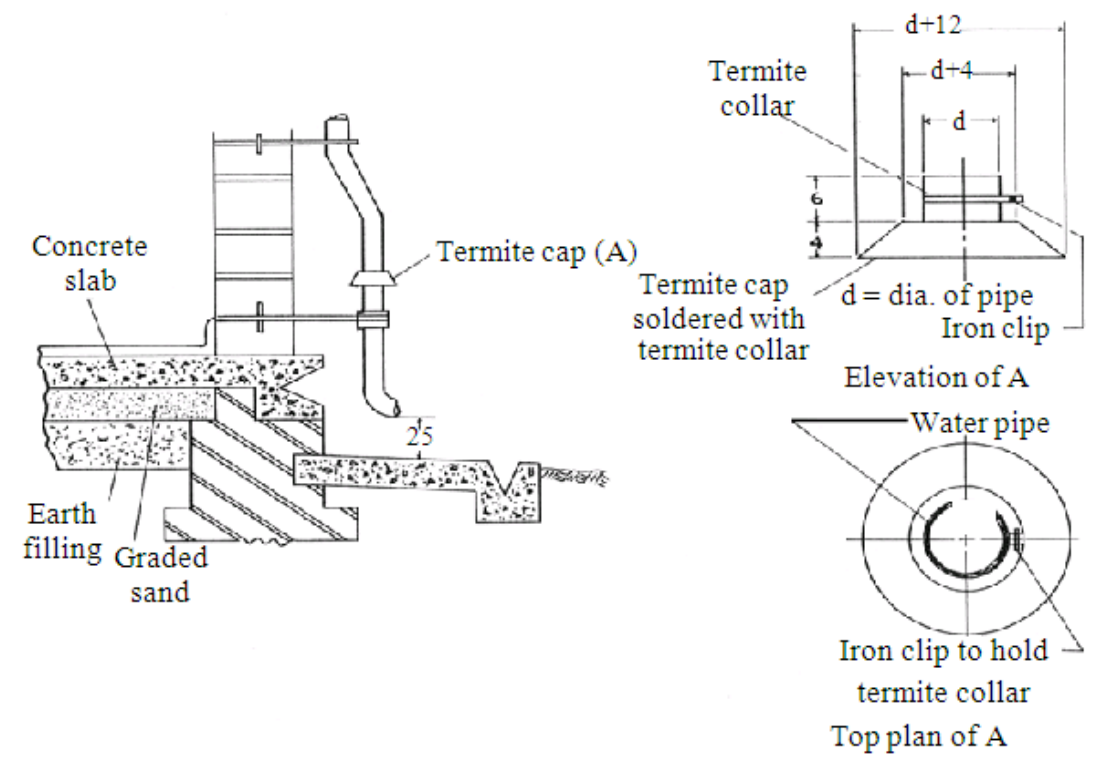

Fig. 5: Anti-termite metal cap for service pipes (Dimensions in $\mathrm{cm}$ )

\section{DISCUSSION}

Termites lifecycle and social structure: Termites live in large colonies in a variety of nests Fig. 6 . The life cycle of termites include 4 stages: eggs, larvae, immature castes and fully developed castes Fig. 7. The eggs produced by the colony queen hatch after 30 days. Upon hatching the larvae (immature termites) resemble small white adults. Through a series of molts (where they shed their skin and increase in size), the immature termites develop into their respective castes. Different castes take a different number of molts to achieve maturity with workers having the shortest molting stage and reproductives having the longest molting stage (Varma et al., 1994; Pearce, 1997; Uys, 2002). 


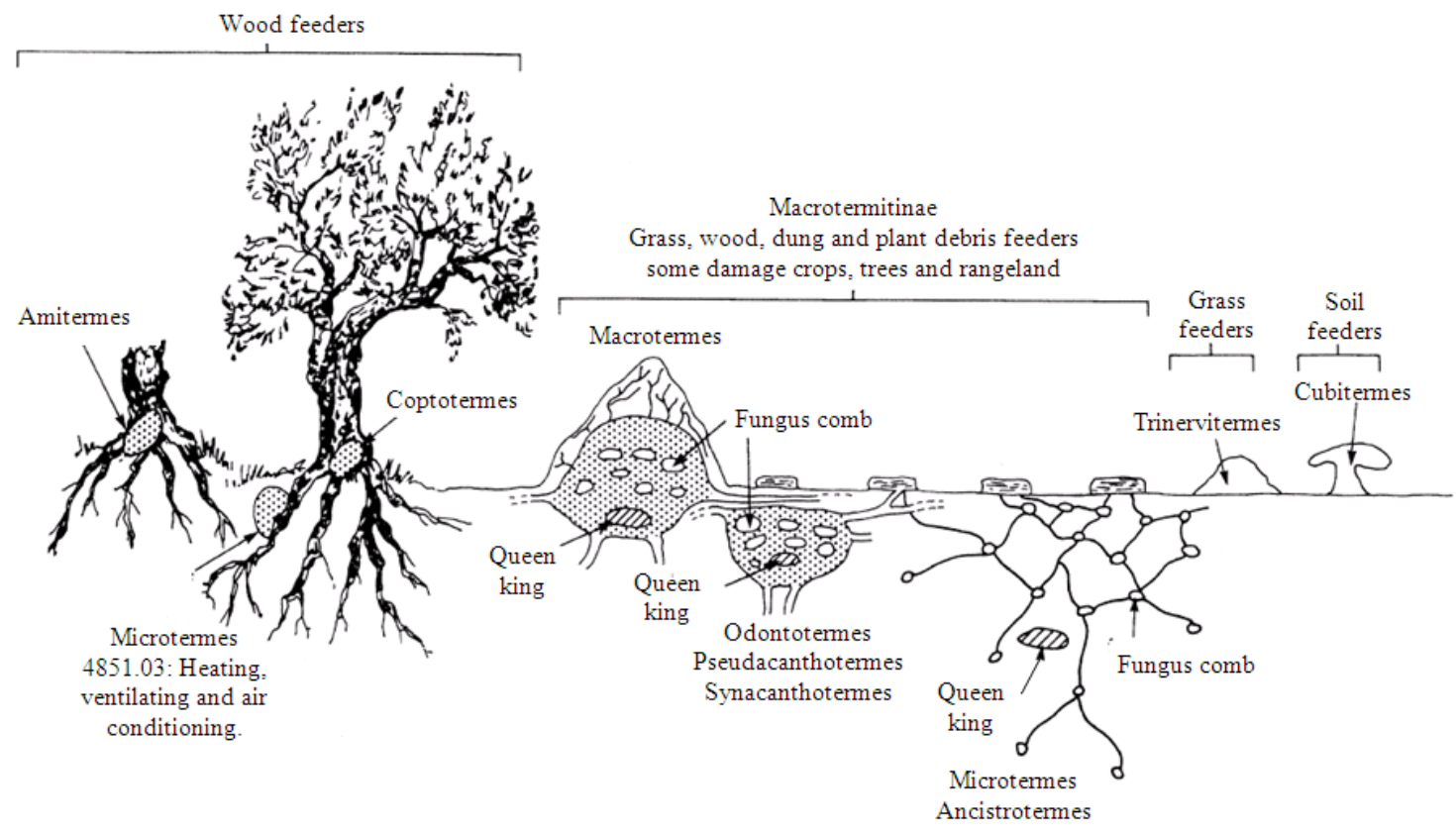

Fig. 6: Termite nests (Wood, 1991)

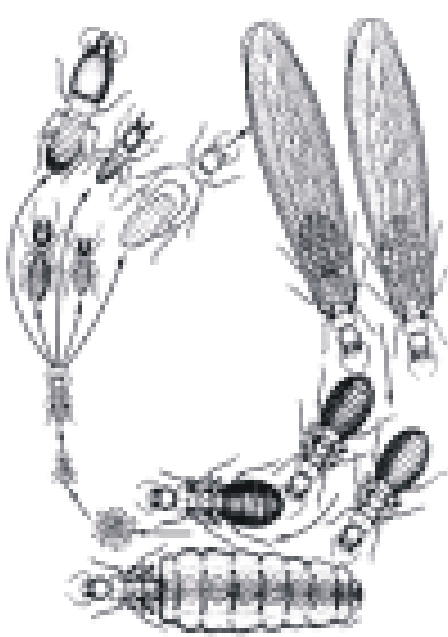

(a)

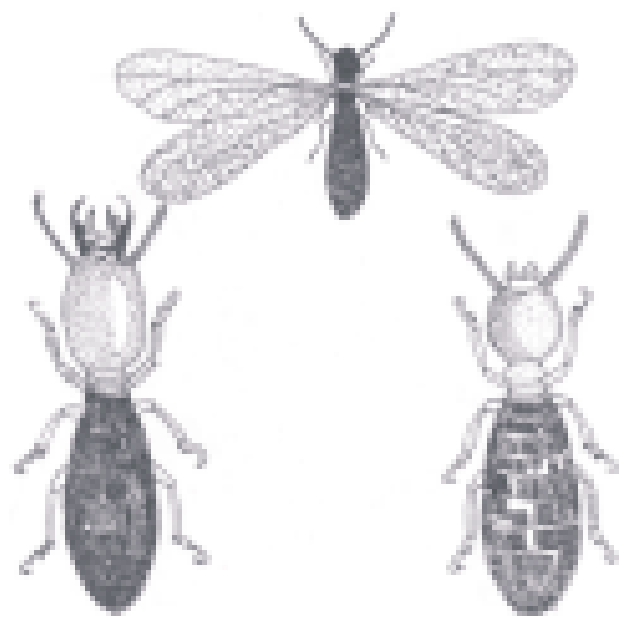

(b)

Fig. 7: Termite life cycle and castes (a) Termite lifecycle (clockwise from top right: alate, dealate, royal pair, eggs, larvae, immature castes, fully developed castes); (b) Termite castes, clockwise from top: alate, worker, soldier (Uys, 2002)

The three specialized termite castes are: (a) reproducers, which supplement the egg production of the primary queen or begin new colonies, (b) workers, which collect food, repair the colony and feed other castes and (c) soldiers, which defend the other castes from attack (Pearce, 1997; Uys, 2002; Korb and Hartfelder, 2008).
Reproducers in a colony come in three general categories: The royal pair, winged alates and supplementary reproductives. The winged alates are freshly hatched reproductive adults that will either remain in the colony to become supplementary reproductive, or travel outside of the nest to settle new colonies in the surrounding area (Uys, 2002; Resh and 
Am. J. Engg. \& Applied Sci., 4 (2): 187-200, 2011

Carde, 2009). Early colonies will not produce any alates as there is a population threshold that must be reached before the queen will produce them. Once they leave the nest in search of new territory, they usually land a few hundred meters away. The release of alates often coincides with fresh rainfall (Resh and Carde, 2009). Once male and female alate pair, they burrow into the nearest potential nesting area, develop a chamber for themselves and begin a transformation from alate to royal pair. For the male, this transformation will be minor as it increases in size a few millimeters larger than its alate form. However, the queen will undergo a tremendous change as its abdomen swells and expands to allow for high egg production (Wagner et al., 2008). The queen`s size depends on the termite species, their location and the number of other queens in the colony. Some, such as queens of the subfamily Coptotermes, will grow a few millimeters (Pearce, 1997). Others, such as the subfamily Macrotermes, will grow $15 \mathrm{~cm}$ long, a size increase of several hundred times (Pearce, 1997). Macrotermes queens can produce eggs at a rate of $30,000-40,000$ per day. Others such as the Macrotermes produce a few hundred eggs per day. The reproductives, especially the queen, have an extended lifetime when compared to other castes. Queens of termite species have been seen to live over 25 years while kings have a substantially shorter lifecycle (Resh and Carde, 2009).

Soldiers act to defend the colony from invasion and tend to have larger heads than other castes of the same species. Their heads grow so large that they are incapable of feeding themselves and rely on the workers of the colony for this. While soldiers are essential to termite colonies in dangerous areas, some tree dwelling species have been observed in their habitats without any visible signs of a soldier caste (Resh and Carde, 2009).

The workers are of most concern to humans as their attempts at foraging and tunneling can result in invasion of timbers and crop fields. Workers expand and repair the colony, locate and prepare food and groom the queen. Since workers play such a crucial role in the health of a colony they are commonly the most prevalent caste in a nest (Verma et al., 2009).

Injurious species of termites in Zambia: Of the over 2,800 different species of termites that are known today, 185 have been recorded as pests in agricultural areas and housing structures (Krishna and Weesner, 1970; Verma et al., 2009). Serious pests, defined as species which regularly necessitate repair work, make up approximately 50 of these 185 species (Pearce, 1997). These injurious species are made up of four genera as shown in Table 3 (Harris, 1971).
Table 3: Injurious termite species (Harris, 1971)

\begin{tabular}{llc}
\hline Genera & Common name & $\begin{array}{l}\text { Number } \\
\text { of species }\end{array}$ \\
\hline Kalotermitidae & Dry wood termites & 10 \\
Mastotermitidae & Australian Mastotermes & 1 \\
Rhinotermitidae & Moist wood subterranean termites & 25 \\
Termitidae & Ground dwelling, mount building & 17 \\
& and tree nesting termites & \\
\hline
\end{tabular}

In Southern Africa, there are currently 165 recorded termite species with 54 distinct genera, of which 10 species are known to cause extensive damage to wood and cellulosic products (Uys, 2002). These 10 species are of the group Rhinotermitidae or the subterranean termites. They live in colonies in rotten wood, ground and construct mud galleries or tubes to protect the workers which forage for food. It is this group that causes wide spread damage to buildings in Zambia. Two other groups (the mound building termites and the dry wood termites) are also found in Zambia, but do not present an economic concern.

Sileshi et al. (2008; 2009) compiled a list of termite species within the Kalomo, Gwembe, Mazabuka, Monze, Choma, Livingstone and Chipata districts of Zambia and found that there were several prevalent pest termite species in the region. These were: Macrotermes falciger, Odontotermes spp., Allodontotermes spp., Microtermes spp., Amitermes truncatidens, Pseudacantthotermes sp. and Macrotermes subhyalinus. Uys (2002) provides an extensive reference on the termite species of southern Africa including biological illustrations and distribution charts which are useful for identification of samples.

Natural durability of wood: There are a variety of parameters which affect the natural ability of wood to resist termite attacks. Among the most relevant are: (a) palatability, (b) repellency and (c) opportunity.

Palatability: Palatability appears to be governed to a large extent by lignin content and hardness (Pearce, 1997). Lignin and cellulose are the major constituents of wood, but whereas cellulose can be digested and used as food by termites, the lignin is thought to be largely excreted and used as a colony construction material (Amelung et al., 2002). Lignin is neither toxic nor repellent to termites (Krishna and Weesner, 1970). Some species of termite have developed symbiotic relationships with fungi which they cultivate in their nests to digest lignin (Cowie et al., 1990). Others have gut flora to assist in lignin digestion (Varma et al., 1994).

Hardwoods have a higher proportion of lignin in their heartwood than in the sapwood (Freeman and Peterson, 1941). The nutrients found in sapwood, 
largely in the form of sugars and starches, render it more palatable than the heartwood of the same tree (Pearce, 1997). However, lignin content is not something which is easily established over a species (Harris, 1971). It is difficult even to make a generalization of chemical composition of hardwoods and softwoods. The location of a hardwood has an impact on the lignin content as tropical hardwoods tend to have a higher lignin concentration than hardwoods from more temperate zones (Findlay, 1975).

There is conflicting opinion in the scientific community as to whether hardness can be directly correlated with termite resistance in wood. Several researchers used wax injection to improve hardness and found a positive correlation between hardness and termite resistance Suzuki and Hagio, 1998 (Scholz et al., 2010), while other studies reached a contrary conclusion (Militiz et al., 2009). Arango et al. (2006) conducted tests to determine the natural durability of a variety of tropical woods to termite damage and found a correlation between the resistances of hardwoods with a high specific gravity to termite attack. However, this observation was not confirmed in softwoods with similar characteristics. This could be due to the fact that softwoods do not have the same ratio of lignin in their heartwood and sapwood and termites are most attracted to cellulose in wood. With a higher lignin to cellulose ratio, the hardwoods would presumably be more resilient to termite attacks.

Repellency: Natural chemical substances are present in some woods in sufficient quantities to drive away termites while other woods may only have sufficient amounts to repel termites after they have eaten a minute particle (Preston and Nicholas, 1982). Extracts of resistant heartwoods have been used to impregnate palatable softwoods to render them termite- repellent for long periods (Harris, 1971; Verma et al., 2009). Lukmandaru and Takahashi (2008) ran a series of experiments on teak timbers to determine their natural repellency. They tested tree samples aged 8, 30 and 51 years and found that the 30 and 51 year old samples were naturally repellent to termites because they both had a considerably higher heartwood percentage than the 8 year old timber.

The distribution of the repellent substances in the living trees is uneven and is affected by the age of the tree and the conditions under which the tree was cut (Arango et al., 2006; Verma et al., 2009; Scholz et al., 2010). There is a great difference between the heartwood and sapwood of the same tree (Campbell and Reece, 2005). The heartwood, due to its age, tends to have a high concentration of repellant material (Arango et al., 2006). As mature forests are depleted, virgin trees are used to supplement the housing market and these young trees may not have the natural repellency that older timbers of the same species would have.

Opportunity: A timber may acquire a reputation for termite resistance in one area and fail in another in which the conditions are favorable for termites or in which a more preferred food is unavailable. Time and a hot, damp climate tend to work in favor of the termites by leaching away or changing the composition of the substances which are the basis of natural resistance in timbers (Ferrar and Watson, 1970; Reddy and Sammaiah, 1991).

The effects of climate on termite attacks were studied by Reddy and Sammaiah (1991). They concluded that rainfall, temperature and relative humidity were the climactic parameters that had the most significant effect on termite attacks. Dryer conditions with low temperature and low relative humidity increased termite attacks. However, isolating these variables resulted in conflicting relationships. For example, as the effects of relative humidity were nullified, temperature was seen to have a positive relationship with termite attacks. This study was conducted in the Calcutta district of India where the most significant structural damage was observed in the winter months. In a different location the results may differ. Therefore, when recording the efficacy of a wood to termite resiliency the environmental parameters used in a study should be related to the proposed site of implementation.

Haverty et al. (1974) performed similar experiments on subterranean termites in Arizona and found that termite foraging was highest in the summer months and lowest in the winter months. The number of termites seen foraging was strongly correlated with temperature. Rainfall had a limited effect on foraging in the winter months but a very strong effect on foraging in the summer months as the number of termites observed dropped sharply at a temperature above $33^{\circ} \mathrm{C}$

An explanation for the diverging findings of Reddy and Sammaiah (1991) and Haverty et al. (1974) is the environments in which the tests were run and the preferential differences displayed by the native species of the different areas. The state of Arizona sits at 31$37^{\circ} \mathrm{N}$ latitude while the Calcutta district sits at $22^{\circ} \mathrm{N}$ latitude. This variation in latitude results in a variation in average annual temperature distribution. The cooler northern area of Arizona would see more termite activity in the warmer summer months while the warmer Indian climate of Calcutta would see more termite activity during the cooler winter months. In the 
winter, Arizona has temperatures which vary between $2-24^{\circ} \mathrm{C}$. During the winter of Calcutta the temperatures vary between $14-32^{\circ} \mathrm{C}$. There is similar variation in summer temperatures in the two locales.

Nature of termite damage to buildings: When a termite colony locates food, workers approach and remove all palatable wood except the outer layers. These outer layers are left to provide shelter to the termites within the wood. However, there are considerable differences in detail among the various groups of termites as shown in Fig. 8.

Dry wood termites eat out galleries in the timber that provide accommodation for the king, queen, soldiers and various young members of the community (Resh and Carde, 2009; Thompson et al., 2000). In time, these galleries coalesce to form large cavities Fig. 8a. The presence of winged nymphs is the first indication of dry wood termite infestation. If these indications are ignored, the presence of termites may continue to be unsuspected until the structure is subject to external stresses (an earthquake, a hurricane or strong winds). Since colonies of dry wood termites consist of only a few hundred individuals, starting from a single pair of flying adults, the infestation builds up slowly and the number of colonies increase till the food supply is exhausted (Rizk and Khalil, 1982; Resh and Carde, 2009; Thompson et al., 2000).

Subterranean termites have fixed nests, with populations numbering in the millions, from which the workers move out in search of food and to which they return with their spoil (Wagner et al., 2008). Distances of up to a hundred yards may be travelled by the small workers with their loads of wood (Pearce, 1997). Thus, the rapidity and scale of their attack on new buildings is much more spectacular than that of dry wood termites. This group of termites constructs earthen tubes over impenetrable foundations and walls to maintain the moist soil environment between nest and food (Wagner et al., 2008). These tubes can travel over steel, resistant wood, or other surfaces which the termites cannot penetrate. When timber is in direct contact with the ground, the termites prefer to approach it from below through tunnels in the soil without any outward signs of entry. A wall of mud bricks or masonry with mud mortar provides a direct and unsuspected route to timber in the roof. Termites are capable of burrowing through the soft mud building materials (Miller and Miller, 2005). A typical indication of subterranean termite infestation is the presence of soil or a mixture of sand and chewed wood in the excavated timber as shown in Fig. 8b (Lai et al., 1982; MRP, 2010).

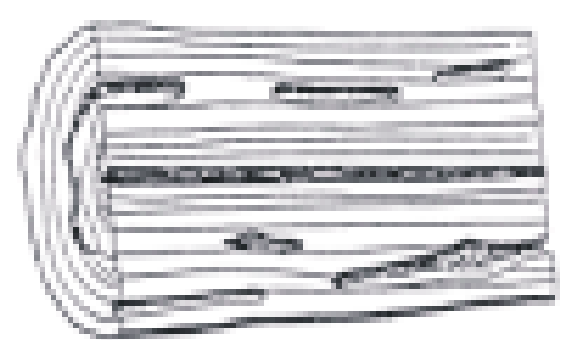

(a)

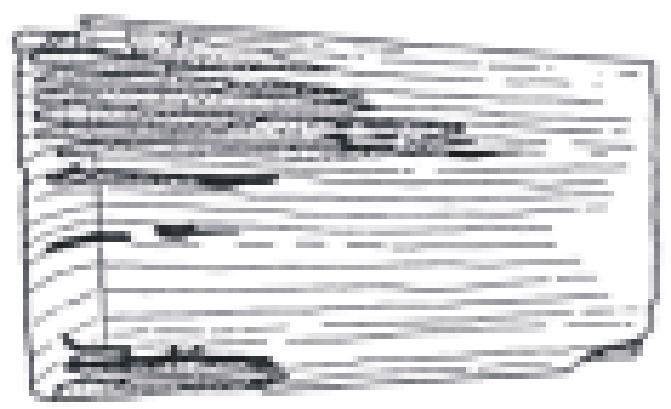

(b)

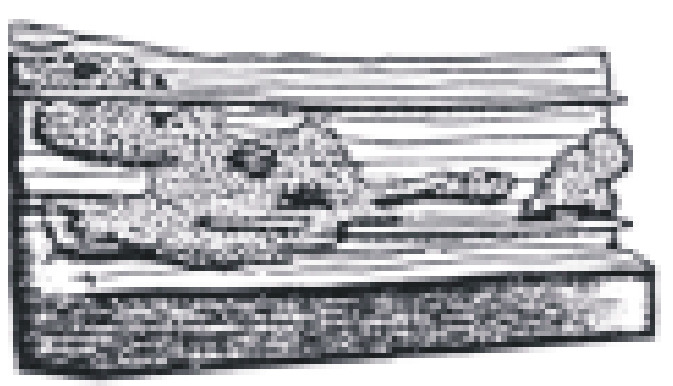

(c)

Fig. 8: Termite wood boring patterns (a) Galleries formed by dry wood termites; (b) A mixture of sand and chewed wood in excavated timber by subterranean termites; (c) Excavated timber space filled with packed earth by mound building termites

Mound buildings termites tend to remove palatable wood, filling the spaces within the remaining thin outer layer with packed earth, to maintain the rigidity of the structure Fig. 8c. Due to the large size of mound building termite nests, the attacks they perform can be devastating to wooden structures. Timber below the ground or encased in masonry tends to disappear entirely.

It is estimated that subterranean termites, inclusive of both mound building and termites in direct contact with soil, account for $95 \%$ of global termite damage (Wagner et al., 2008). 
Am. J. Engg. \& Applied Sci., 4 (2): 187-200, 2011

Table 4: List of chemicals used as wood preservatives

\begin{tabular}{|c|c|c|c|}
\hline Types of preservatives & Preservative name & Reference & Notes \\
\hline \multirow[t]{3}{*}{ Gas } & Methyl Bromide & Verma et al. (2009) & $\begin{array}{l}\text { Methyl Bromide was phased out in } 2005 \\
\text { due to high toxicity to humans. }\end{array}$ \\
\hline & Phosphine & Pearce (1997) & \\
\hline & Chloropicrin & Pearce (1997) & \\
\hline \multirow[t]{4}{*}{ Solid } & Aldrin & Kohler (2006) & Aldrin has been banned in several \\
\hline & Benzene hexachloride & Kohler (2006) & developed countries since 1995 \\
\hline & Calcium arsenate & Magalhaes (2003) & \\
\hline & Orthodichlorobenzene & EPA (1993) & \\
\hline \multirow[t]{2}{*}{ Liquid } & Carbon disulphide & Evans (2003) & \\
\hline & Coal tar creosote & Cassens et al. (1995) & \\
\hline \multirow[t]{5}{*}{ Organic } & Chlordane & Verma et al. (2009) & Due to concerns regarding human health \\
\hline & Copper naphthenate & Cassens et al. (1995) & chlordane has been banned in several \\
\hline & Dichlorodiphenyle- trichloroethan & Forest Products Lab (1974) & countries since the late $1980 \mathrm{~s}$ \\
\hline & Pentachlorophenol & Choudhury et al. (1986) & \\
\hline & Lindane & Pearce (1997) & \\
\hline \multirow[t]{6}{*}{ Water soluble } & Arsenic & Findlay (1975) & \\
\hline & Boron & Findlay (1975) & \\
\hline & Chrome & Findlay (1975) & \\
\hline & Copper & Findlay (1975) & \\
\hline & Fluor & Findlay (1975) & \\
\hline & Metal Salts & Pearce (1997) & \\
\hline
\end{tabular}

Faulty construction practices: Improper timber selection and use can lead to termite penetration of buildings. Timber should be kept out of contact with the ground to ensure that there is no opportunity of termite attack. If timber must be put into the ground it should be a naturally resilient or treated wood. However, where possible, the use of timber in direct contact with the ground should be avoided as the natural durability and the effects of preservation will wear down due to the effect of aging. After several years, the repellency may not be strong enough to keep termites at bay. The foundation is another potential method of termite entry. Where the foundation is dirt, clay or otherwise easily burrowed through, termites can gain entry by directly digging up through the earth. If the foundation is noncontinuous, cracked or otherwise compromised, termites can gain entry from the earth below the structure. Wall joints, if incorrectly sealed, offer a method of termite entry. If any gaps exist between the foundation and the walls, termites may gain access to structures through tunneling between these gaps. Termites can also easily gain access through the holes in the roof.

Chemical control of termites: Timber may be protected from attack by the introduction of an adequate amount of poisonous chemical or repellent. In order for treatment to be effective, the chemical must: (a) remain in the timber over a long period of time, (b) penetrate to a considerable depth within the wood, (c) be noncorrosive to the wood itself, (d) not increase the flammability of the treated wood and (d) be sufficiently toxic to prevent insect attack while remaining non-toxic to humans during and after application (Findlay, 1975; Hanel and Watson, 1983; Verma et al., 2009) GEI, 2005. The search for new chemicals to protect timber from termites is an active field of study. Table 4 presents a sample of the various types of chemical treatments in use. When evaluating the robustness of a chemical treatment the chemical should be tested under a variety of conditions including high temperature and humidity. These parameters should also be adjusted to test for the effect of leaching when the timber is in contact with soil moisture, or unprotected from rain. The choice of a chemical (or formulation of several chemicals) that is/are effective against the termites in a particular area and under the conditions in which the treated timber will be used is very important (Reddy and Sammaiah, 1991; Verma et al., 2009; Scholz et al., 2010).

Identifying the local termites is also important so that an effective level of treatment can be applied. Termites vary greatly in their susceptibility to different chemicals and as a result the dosage that is effective in one locality could be inadequate in another. For example, a dose of fluorine and copper compounds to the hardwood of particleboard was effective at reducing attack by Kalotermes flavipes but did not stop Heterotermes indicola from developing galleries in the sample (Becker, 1972). Similar variation in results was observed by Becker, (1972) for particle board treated with fungicidal compounds and Hydrogen fluoride.

The suitability of timber for impregnation process or the degree of resistance to wood preservatives must also be assessed. Generally, sapwood can be impregnated successfully, while heartwood is difficult 
to treat (Levin, 1971; Findlay, 1975; Cassens et al., 1995). The same factor that makes sapwood suitable for preservation (its ability to readily absorb liquid) also makes it more susceptible to natural degradation. Unless properly treated, sapwood is non-durable when exposed to conditions favorable to decay (Cassens et al., 1995). Treating a wood with a preservative can be done in a variety of ways.

Three of the most common techniques are: (a) brushing, spraying or dipping techniques, (b) the hot and cold open tank technique and (c) the diffusion technique.

Brushing and spraying techniques are simple and relatively inexpensive. These treatments coat the timber in a thin layer of material which termites find repellent or unpalatable (Cassens et al., 1995). These techniques are most effective when using a highly adsorptive timber and a low viscosity preservative. If timber is already in place, brushing and spraying are the easiest methods of applying a preservative. In order for these techniques to be effective the preservative must be reapplied on a regular basis.

Dipping in open tanks is better than brushing and spraying as it ensures complete coverage of the treated timber. The optimum soak time is dependent on the permeability of the treated timber, the environment in which it will be used and the viscosity of the preservative (Findlay, 1975; Cassens et al., 1995). The American Wood Preservers' Association offers retention level based standards for a variety of timbers, environmental conditions and preservatives (AWPA, 2010). Cassens et al. (1995) recommended a minimum soak time of three minutes. However, a longer soak will result in a deeper penetration of preservative and, therefore, a more robust wood preservation.

The hot and open tank treatment requires at least one tank with a source of heat. The idea is to heat up the timber in the preserving fluid for two hours or more at a temperature of $100^{\circ} \mathrm{C}$, depending on the crosssection of the timber. This will expand the air in the timber and allow for the preservative to enter (Cassens et al., 1995). The timber is then cooled in order to improve the absorption of preservative. This can be accomplished in the open air or in a cold water bath. Cassens et al. (1995) recommend a cooling time of a minimum of 2 hours. Dip treatment is often limited by the size of timber that can be treated. A dipping tank larger than the treated timber is required for complete submersion which can be an economically limiting factor during preservation treatment.

Impregnation by diffusion is a process whereby preservatives are introduced into freshly cut timber. The preservative is sprayed onto stacked timber, stored under conditions of ventilation to allow it to dry slowly and the chemicals to diffuse naturally through the timber.

Biological Control of Termites

Research on biological alternatives to control of termites is being carried out by several researchers (Ochiel et al. 1997; Kohler, 2006; Verma et al. 2009). Verma et al. (2009) conducted an extensive review of available biological alternatives for termite control and found four basic treatment categories: (a) botanicals, (b) nematode, (c) bacterial and (d) fungal.

Botanicals (oils, leaves, resins, roots and woods) were found to adjust termite growth rates, reduce the frequency of termite feeding and have high toxicity levels to select species (Verma et al., 2009).

Nematodes are small wormlike creatures that live in oceans, freshwater and soils (Guerana, 2006). Many nematode species are microscopic in size and are economically important pests as they damage plants (Schmitt and Sipes, 2000; Guerana, 2006). However, two families of nematode, the Steinernematidae and the Heterorhabditidae, are parasitic and lethal to termites (Verma et al., 2009).

Bacteria, Rhizobium radiobacter, Alcaligenes latus and Aeromonsa caviae, can also be used to kill or control a termite colony as they release hydrogen cyanide. Similar results were found with fungi (Verma et al., 2009).

All biological controls are highly specific to termite species. Therefore, a survey of the species being treated should be made before an appropriate biological solution can be selected. The side effects should also be taken into consideration.

Control of termites by construction methods: Where available treated wood, or naturally resistant wood, should be used to reduce termite activity. However, these can last for several years as the natural resins and synthetic chemicals will wear down and timber will be susceptible to termite attack. Alternatively, a chemical treatment could be used or a species specific approach could be adopted where biological controls could be put in place to reduce termite activity. While chemical treatments using Persistent Organic Pollutants (POPs) are effective in controlling termite damage, there are concerns regarding the impact of these chemicals on the environment Stockholm Convention, 2001. POPs are a group of industrial chemicals, mostly halogenated hydrocarbons, which tend to bio-accumulate in fatty tissues and can, individually or interactively, result in a variety of health effects such as tissue, organ and sex related deficiencies (Safe, 2000; Kohler, 2006). The international guidelines of the 2001 Stockholm 
Convention identified 12 of these POPs for elimination from global circulation (Kohler, 2006). Over 70 countries have established national implementation plans for the elimination of these POPs.

Thus, the simplest method of dealing with structural damage due to termites would appear to be building the structures in a preventative manner to avoid initial termite damage. Houses built of concrete, metal and glass are not necessarily termite proof unless they have been designed to deny access to termites which are capable of damaging furniture, decorative fabric and books. Constructional preventative measures may lead to an easy to build all proof, effective and economical answer to preventing termite entry into buildings (Ahmed and French, 2005).

To prevent termite entry into buildings, the site must be cleared of all nests and all wood material such as tree roots and wood waste liable to attract termites. Termiticides must be applied to provide a chemical barrier between the slab and ground. All timber used must be naturally resistant or impregnated with a chemically based preservative and the wood foundation must be placed over a concrete footing. Buildings must have internal preventive measures within the plinth consisting of well-rammed clean earth filling, a staggered sand layer and a continuous concrete slab extending over the entire plinth area. Continuous concrete slabs act as barriers against termite entry and prevent dampness from accumulating and damaging structural timber. Slabs should not be broken to allow pipes to pass through them, nor should any waste pipes be allowed to touch the projecting edges as they will form bridges over which the termites can by-pass the barrier. Buildings must also have an external preventive measure in the form of concrete grooves and interlocking apron floors around the periphery. Antitermite metal caps should be used for service pipes.

\section{CONCLUSION}

In view of the extensive and serious damage caused to buildings by termites in the tropics, it is necessary to take all relevant precautions in the design and building specifications to incorporate anti- termite constructional measures in all future buildings. The results of the study indicated that termites can enter buildings through a variety of pathways. If unprotected the floors, walls and roofs of structures offer easy entry to termites. By combining chemical, physical and natural termite prevention strategies a structure can be made resistant to termite attacks. Once a code of practice is developed and enforced, termite damage to buildings and crops in these areas can be reduced to minimal levels. This will allow for more homeowner freedom and an increase in disposable income.

\section{ACKNOWLEDGEMENT}

This research was supported by the Canadian International Development Agency (CIDA)

\section{REFERENCES}

Ahmed, B.M. and J.R.J. French, 2005. Report and recommendations of the national termite workshop, Melbourne. Int. Biodeterioration Biodegradation, 56: 69-74. DOI: 10.1016/j.ibiod.2005.05.001

Amelung, W., C. Martius, A.G. Bandeira, M.V.B. Garcia and W. Zech, 2002. Lignin characteristics and density fractions of termite nests in an Amazonian rain forest-indicators of termite feeding Guilds? Soil Biol. Biochem., 34: 367-372. DOI: 10.1016/S0038-0717(01)00192-4

Arango, R.A., F. Green, K. Hintz, P.K. Lebow and R.B. Miller, 2006. Natural Durability of tropical and native woods against termite damage by Reticulitermes flavipes (Kollar). Int. Biodeterioration Biodegradation, 57: 146-150. DOI: $10.1016 / \mathrm{J}$.ibiod.2006.01.007

AWPA, 2010. 2010 AWPA Book of standards. American Wood Protection Association.

Becker, G., 1972. Protection of wood particle board against termites. Wood Sci. Technol., 6: 239-248. DOI: 10.1007/BF00351581

Black, H.I.J. and M.J.N. Okwakol, 1997. Agricultural intensification, soil biodiversity and agroecosystem function in the tropics: The role of termites. Applied Soil Ecol., 6: 37-53. DOI: 10.1016/S09291393(96)00153-9

Campbell, N.A. and J.B. Reece, 2005. Biology. 7th Edn., Pearson, Benjamin Cummings, New York, ISBN: 0805371710, pp: 1231.

Cassens, D.L., B.R. Johnson, W.C. Feist and R.C. DeGroot, 1995. Selection and Use of PreservativeTreated Wood. 1st Edn., Forest Products Society. Madison, Wi. ISBN: 0935018751, pp: 104.

Choudhury, H., J. Coleman, C.T. De Rosa and J.F. Stara, 1986. Pentachlorophenol: health and environmental effects profile. Toxicol. Indus. Health, 2: 483-571. DOI: 10.1177/074823378600200409 PMID: 3590200

Cowie, R.H., T.G. Wood, E.A. Barnett, W.A. Sands and H.I.J. Black, 1990. A checklist of the termites of Ethiopia with a review of their biology, distribution and pest status. Afr. J. Ecol., 28: 21-33. DOI: $10.1111 /$ j.1365-2028.1990.tb01133.x 
Dawes, T.Z., 2010. Reestablishment of ecological functioning by mulching and termite invasion in a degraded soil in an Australian savanna. Soil Biol. Biochem., 42: 1825-1834. DOI: 10.1016/j.soilbio.2010.06.023

Donovan, S.E., G.J.K. Griffiths, R. Homathevi and L. Winder, 2007. The spatial pattern of soil-dwelling termites in primary and logged forest in Sabah, Malaysia. Ecol. Entomol., 32: 1-10. DOI: 10.1111/j.1365-2311.2006.00856.x

Donovan, S.E., P. Eggleton, W.E. Dubbin, M. Batchelder and L. Dibong, 2001. The effect of a soil-feeding termite, Cubitermes fungifaber (Isoptera: Termitidae) on soil properties: Termites may be an important source of soil microhabitat heterogeneity in tropical forests. Pedobiologia, 45: 1-11. DOI: 10.1078/0031-4056-00063

Evans, P., 2003. Emerging technologies in wood protection. Forest Products J.

Ferrar, P. and J.A.L. Watson, 1970. Termites (isoptera) associated with dung in Australia. J. Australian Entomol. Soc., 9: 100-102. DOI: 10.1111/j.14406055.1970.tb00778.x

Findlay, W.P.K., 1975. Timber: Properties and Uses. 1st Edn., Crosby Lockwood Staples, London, pp: 224.

Forest Products Laboratory, 1974. Wood Handbook: Wood as an Engineering Material. 1st Edn., The Laboratory, USA., pp: 431.

Freeman, R. and F. Peterson, 1941. Proximate analysis of the heartwood and sapwood of some American hardwoods. Indus. Eng. Chem. Anal. Edn., 13: 803-805. DOI: $10.1051 / \mathrm{i560099a016}$

Guerana, M., 2006. Nematodes: Alternative Controls. 1st Edn., National Sustainable Agriculture Information service. Fayetteville, Ar.

Hanel, H. and J.A.L. Watson, 1983. Preliminary field tests on the use of Metarhizium anisopliae for the control of Nasutitermes exitiosus (Hill) (Isoptera: Termitidae). Bull. Entomol. Res., 73: 305-313. DOI: $10.1017 / \mathrm{S} 0007485300008890$

Harris, W.V., 1971. Termites: Their recognition and control. 2nd Edn., Longman, London, ISBN: 0582466563, pp: 186 .

Haverty, M.I., J.P. LaFage and W.L. Nutting, 1974. Seasonal activity and environmental control of foraging of the subterranean termite, heterotermes aureus (Snyder), in a desert grassland. Life Sci., $\begin{array}{llll}\text { 15: } 1091-1101 . & \text { DOI: } 10.1016 / \mathrm{S} 0024- \\ 3205(74) 80006-8 & & \end{array}$
Kohler, P.M., 2006. Science, PIC and POPs: Negotiating the membership of chemical review committees under the Stockholm and Rotterdam conventions. Rev. Eur. Community Int. Environ. Law, 15: 293-303. DOI: 10.1111/j.14679388.2006.00531.x

Korb, J. and K. Hartfelder, 2008. Life history and development-a framework for understanding developmental plasticity in lower termites. Biol. Rev., 83: 295-313. DOI: 10.1111/j.1469185X.2008.00044.X

Krishna, K. and F.M. Weesne, 1970. Biology of Termites. 1st Edn., Academic Press, New York, pp: 598.

Lai, P.Y., M. Tamashiro and J.K. Fuji, 1982. Pathogenicity of six strains of entomogenous fungi to Coptotermes formosanus. J. Invertebrate Pathol., 39: 1-5. DOI: 10.1016/0022-2011(82)90150-1

Levin, E., 1971. Wood in Building. 1st Edn., Architectural Press, London, ISBN: 0851397166. pp: 153 .

Resh, V.H. and R.T. Carde, 2009. Encyclopedia of Insects. 2nd Edn., Elsevier/Academic Press, Burlington, MA., ISBN: 0123741440, pp: 1132.

Lukmandaru, G. and K. Takahashi, 2008. Variation in the natural termite resistance of teak (Tectona grandis Linn. Fil.) wood as a function of tree age. Ann. For. Sci., 65: 708-715. DOI: 10.1051/forest:2008047

Miller, M.R., 2005. Miller's Guide to Foundations and Sitework. 1st Edn., McGraw-Hill, New York, ISBN: 0071451455, pp: 212.

MRP, 2010. Maxwell Robinson Phelps Termite Report. Maxwell, Robinson and Phelps.

Magalhaes, M.C.F., 2003. Arsenic. An environmental problem limited by solubility. Pure Applied Chem., 74: 1843-1850. DOI: 10.1351/pac200375010139

Ochiel, G.S., H.C. Evans and J. Eilenberg, 1997. Cordycepioideus, a pathogen of termites in Kenya. Mycologist, 11: 7-9. DOI: 10.1016/S0269915X(97)80059-6

Pearce, M., 1997. Termites: Biology and Pest Management. 1st Edn., CAB International, Chatham, UK., ISBN: 0851991300, pp: 172

Preston, A.F. and D.D. Nicholas, 1982. Efficacy of a series of alkylammonium compounds against wood decay fungi and termites. Wood Fiber Sci., 14: 3742.

Reddy, M.V. and C. Sammaiah, 1991. Combined effects of climatic factors on the seasonal termite damage to structural wood in a semi-arid urban system. Energy Buil., 16: 947-955. DOI: 10.1016/0378-7788(91)90089-L 
Rizk, M. and F.M. Khalil, 1982. Effect of thermorhythm on termite food consumption. Assiut J. Agric. Sci., 13: 43-53.

Safe, S.H., 2000. Toxicology of persistent organic pollutants. Eur. J. Lipid Sci. Technol., 102: 52-53. DOI:

$10.1002 /(\mathrm{SICI}) 1438$ 9312(200001)102:1<52::AID-EJLT52>3.0.CO;2-R

Salman, A.G.A., H.M. Hussein, M.A. Morsy and A.A. El-Sayed, 1982. Preliminary report on the control of subterranean termites in Egypt. Assiut J. Agric. Sci., 13: 229-246.

Schmitt, D.P. and B.S. Sipes, 2000. Plant-parasitic nematodes and their management. In: Plant Nutrient Management in Hawaii's Soils, Approaches for Tropical and Subtropical Agriculture, Silva, J.A. and R. Uchida, (Eds.). University of Hawaii, Manoa, pp: 145-149.

Scholz, G., H. Militz, P. Gascon-Garrido, M.S. IbizaPalacios and J.V. Oliver-Villanueva et al., 2010. Improved termite resistance of wood by wax impregnation. Int. Biodeterioration Biodegradation, 64: 688-693. DOI: 10.1016/j.ibiod.2010.05.012

Sileshi, G.W., E. Kuntashula, P. Matakala and P.O. Nkunika, 2008. Farmer's perceptions of tree mortality, pests and pest management practices in agroforestry in Malawi, Mozambique and Zambia. Agroforestry Syst., 72: 87-101. DOI: 10.1007/s10457-007-9082-5

Sileshi, G.W., P. Nyeko, P.O.Y. Nkunika and B.M. Sekematte, 2009. Integrating ethno-ecological and scientific knowledge of termites for sustainable termite management and human welfare in Africa. Ecol. Soc., 14: 48-48.

Thompson, G.J., L.R. Miller, M. Lenz and R.H. Crozier, 2000. Phylogenetic analysis and trait evolution in Australian Lineages of Drywood Termites (Isoptera, Kalotermitidae). Molecular Phylogenetics Evol., 17: 419-429. DOI: 10.1006/mpev.2000.0852
Tsunoda, K., 2005. Improved management of termites to protect Japanese homes. Proceedings of the 5th International Conference on Urban Pests, Perniagaan Ph'ng, Malaysia, pp: 33-37.

Uys, V., 2002. A Guide to the Termite Genera of Southern Africa. 1st Edn., Plant Protection Research Institute Agricultural Research Council, Pretoria, ISBN: 1-86849-216-8, pp: 116.

Varm, A., B.K. Koli, J. Paul, S. Saxena and H. Konig, 1994. Lignocellulose degradation by microorganisms from termite hills and termite guts: A survey on the present state of art. FEMS Microbiol. Rev., 15: 9-28. DOI: 10.1016/01686445(94)90024-8

Verma, M., S. Sharma and R. Prasad, 2009. Biological alternatives for termite control: A review. Int. Biodeterioration Biodegradation, 63: 959-972. DOI: 10.1016/j.ibiod.2009.05.009

Wagner, M.R., J.R. Cobbinah and P.P. Bosu, 2008. Forest entomology in west tropical Africa: Forest insects of Ghana. 2nd Edn., Springer, New York, ISBN: 140206506X, pp: 244.

Watson, J.A.L. and D.H. Perry, 1981. The Australian harvester temites of the genus Drepanotermes (Isoptera: Termitinae). Aus. J. Zoology Supplementary Series. 29: 1-153. DOI: 10.1071/AJZS078

Wood, T.G., 1991. Termites in Ethiopia: The environmental impact of their damage and resultant control measures. Ambio, 20: 136-138. 